\title{
The Position of the Scientific Worker.
}

\begin{abstract}
$\mathrm{A}^{\mathrm{T}}$ the annual council meeting of the National Union of Scientific Workers, held at the Caxton Hall, Westminster, on January I $_{3}$, and at the annual dinner which followed, the main theme of the resolutions which were adopted, of the various speeches made, and of the reports presented, was the methods by which the position of the scientific worker could best be improved. The late Government, it was alleged, had adopted a short-sighted policy with regard to most of those State activities which promised to have the most uplifting and far-reaching effect upon the efficiency and well-being of the nation. It had practised so-called economy by reducing expenditure on education and scientific research, at a time when our chief commercial rivals were increasing their expenditure in that direction.
\end{abstract}

To the want of appreciation and understanding of the importance of science by the members of the late Government, culminating in drastic reductions in the various research departments, were attributed most of the present troubles of scientific workers. Within the past twelve months " economies" have been effected in those departments of the State and municipal services which do not show an immediate return for the money expended. The inevitable effect will be stagnation in peace, and in war hurried, and therefore uneconomical, research. It is true that the Geddes Committee last year expressed the view that there is little possibility of a further war of any magnitude for the next ten years; but just as their prognostications in that respect appear doubtful at the moment, judged by the trend of current events, so is their corollary to the effect that research in this country can either be slowed down, or, in some instances, abandoned altogether. This is a doctrine of despair, and was characterised as such by members of the council of the Union, and by their guests, Sir Thomas Holland, Mr. William Graham, and Mr. H. N. Brailsford.

Mr. Graham said that there were three aspects of the work of the National Union of Scientific Workers which particularly interested him. The Union must be interested in conditions of employment and remuneration, and he felt that it was a serious mistake, if not a positive crime on the part of the community, to starve the body of investigators upon whose efforts so much depends. The Union would also be alive to the importance of according greater recognition to the work of the universities, and to the contribution that science can make to the restoration of economic prosperity in the world. He thought there was a distinct danger to the universities in the present economy campaign. Before the war the country was making only a limited provision for the universities and other educational institutions. As a member of the Oxford and Cambridge Universities Commission, he had had an opportunity of making a careful examination of university departments and university finance, and he hoped that the Bill to be presented to Parliament next session would result in the present grant being more than trebled. It would not do to rely in the future, as in the past, on philanthropy. Much larger sums of public money would be required, and scientific workers could argue strongly that they did not claim it selfishly, but for the benefit conferred on the nation by their investigations. The methods of science are needed in these days of reconstruction, and if adopted would undoubtedly increase production and help in resisting the lowering of the standard of life, which is a pressing danger in every country. Sir Thomas Holland fully endorsed these views, adding that the Government should understand that at least 80 per cent. of the expenditure of a teaching and researoh institution must be disbursed as salaries to the staffs. A strong and united body of scientific workers is a necessity if salaries are to be improved and the right atmosphere created. Unfortunately the dignity of the work in most people's eyes is apt to be commensurate with the sums paid for it, so there is every reason why the Union should put the question of remuneration in the forefront.

Dr. Alan A. Griffith, the retiring president, in his address, dealt with this matter from a rather different point of view. He suggested that scientific workers should free themselves from the necessity of having to beg from their beneficiaries the wherewithal to improve the efficiency of their labours, by setting up a business organisation for the exploitation of their discoveries and inventions. In providing specifically for the evolution of great inventions based on pure research, it would fill the gap between science and industry, which has, in the past, so seriously hampered the material utilisation of scientific discoveries.

\section{The Hydrogen-ion Concentration of Sea Water.}

A RECENT number of the Journal of the Marine Biological Association (vol. xii., No. 4, October I922) contains a series of papers by Dr. W. R. G. Atkins which make a contribution of conspicuous value towards our knowledge of the fundamental conditions that control vital production in the sea. After a short review of the literature the author considers what lines of research his study indicates, and then follow six memoirs which deal, in the most interesting way possible, with some of the problems that have suggested themselves.

First in importance is a series of determinations of the $\mathrm{H}$-ion concentration in the open sea between Plymouth and Ushant, and round Land's End into the mouth of the Bristol Channel. In the open sea the " $p H$ " values varied between 8.27 and 8.14 ; round Land's End the variation was between $8 \cdot 18$ and 8.14, and in Plymouth Sound it was about 8.10. Now " $p \mathrm{H}$ " means the logarithm of the reciprocal of $\mathrm{H}$-ion concentration expressed in grams per litre of water. High values (up to about Io) mean high values of the " alkalinity" as represented, for example, by the quantity of N/Ioo acid necessary to decolorise sea water made pink by the addition of phenolphthalein. Low values (down to about 6) mean "acidity" of the sea water by reason of the presence of unusually large quantities of carbonic acid.

Biological relationships are associated with these variations in the $p \mathrm{H}$-values. Thus, there is a decrease of about 0.05 between high and low water, and this is due to the influence of the water draining away from the shore zones; over a bed of Laminaria the water was more alkaline than in the immediate neighbourhood, and in rock pools $p \mathrm{H}$ sank by as much as 0.25 : this is the result of photosynthesis by algæ which remove carbonic acid. In the aquarium tanks the $p \mathrm{H}$-values sink to $7 \cdot 6$. When it is less than this, carbon dioxide is in excess, and at 7.3 there is evident distress in the respiration of fishes. At $7 \cdot I$ the water becomes

$$
\text { NO. } 2778 \text {, VOL. I I I ] }
$$

